\title{
Public vs Private Space of Parking: Zoning, Accessibility, and Etalage
}

\section{Triyatni Martosenjoyo}

Hasanuddin University, Indonesia. Email: triyatni@unhas.ac.id

\begin{tabular}{|c|c|}
\hline ARTICLE INFO & ABSTRACT \\
\hline $\begin{array}{l}\text { Keywords: } \\
\text { Parking space; public; } \\
\text { private; etalage; social } \\
\text { status. } \\
\text { How to cite: } \\
\text { Martosenjoyo, T., (2020). } \\
\text { Public vs Private Space of } \\
\text { Parking: Zoning, } \\
\text { Accessibility, and Etalage. } \\
\text { ETNOSIA: Jurnal } \\
\text { Etnografi Indonesia. 5(2): } \\
252 \text { - 264. } \\
\text { DOI: } \\
\text { 10.31947/etnosia.v5i2.10786 }\end{array}$ & $\begin{array}{l}\text { Public parking spaces are facilities that support the activities of } \\
\text { urban residents with relatively high mobility. As with all definitions } \\
\text { of public spaces, public parking space facilities are assumed to be } \\
\text { accessible to everyone without questioning their status. Several } \\
\text { different things are found in public parking spaces in higher } \\
\text { education institutions at UNHAS. This research examines the } \\
\text { meaning of public parking spaces for UNHAS people and how they } \\
\text { are connected to these facilities. The study was conducted at the } \\
\text { Tamalanrea UNHAS campus. Data were collected using in-depth } \\
\text { interviews to explore how they perceive zoning meanings, } \\
\text { accessibility of public parking spaces, the signages placed there, and } \\
\text { observations surrounding campus parking spaces. The interview } \\
\text { involved } 140 \text { informants consisting of structural officials, lecturers, } \\
\text { employees, students, and guests. The results showed that, in practice, } \\
\text { the public parking space of UNHAS had become a private space } \\
\text { because it cannot be accessed and used freely by everyone, except } \\
\text { those with specific social status as written on parking signs (i.e., } \\
\text { rector, vice-rector). It is also found that parking spaces have become } \\
\text { an etalage for displaying and promoting the personal social status of } \\
\text { UNHAS officials. }\end{array}$ \\
\hline
\end{tabular}

\section{Introduction}

As cultural creatures, humans not only need to interact with people they know who have the same culture, but also to interact with strangers. This is important so that humans can enrich their insights about the diversity of cultural differences and existing identities. Places to interact with strangers freely can be done in public spaces, such as city parks, streets, markets, community centers, gathering centers and others. Public space is a place for dialogue and cultural exchange (United Nations Educational, 2017). Well-designed and well-maintained public spaces are essential for the health of any city. Such meeting space allow for social interaction, citizen participation, recreation and ownership.

Human movement from one activity room to another for a relatively $\backslash$ far distance using vehicles such as bicycles, motorcycle or cars. Therefore, human activity centers 
are required to have adequate public parking space facilities as temporary vehicle stops to carry out activities at any time (Dirjen Perhubungan Darat, 1996:1). In urban areas, public space means that the space is open and accessible to all people or members of the community without the need to question people's status. Public space publicity is openness for everyone where individuals and groups are free to come and go, free to use space for their intended purposes (Habermas, 1991:2; Neal, 2010:1-2). When freedom is restricted, public space loses its publicity.

Generally, people assume that space and place are empty containers that are neutral and not connected to each other. Human geographical conditions show that space and place are relational, socially managed, and dynamic. What happens in public space is contextual and varies from time to time. People understand public space differently and are local. Therefore, the perception that there is equality in the practice of the use of public space does not occur immediately but changes from time to time (Koops \& Galič, 2017:23-24; Tilley, 1994:9).

As a public institution, Hasanuddin University (UNHAS) with a population of around 30,000 people provides public parking spaces that can be used by residents and university guests to put their vehicles when not being used. The parking spaces are spread out around the activity area and merge with UNHAS's shady and artificial forests. Visually, this public parking space is equipped with a variety of signs that symbolically convey the messages that the space is not freely accessed as it is attached to one's certain status.

Researches on parking spaces in urban areas generally focus on the privatization of public spaces as a source of financial business, including public parking spaces (Ashton et al., 2012; Nasution \& Zahrah, 2012; Auchincloss et al., 2015). In these cases, the discussion focuses on how access to public parking spaces can only be done by paying a certain amount of money to the parking space management. Those who do not have money to pay cannot take advantage of these public parking spaces. Here there are lost public rights as a result of public space being used as a source of stages for the public parking facilities management.

This article is different, because it does not deal with the problem of privatization as discussed by previous researchers, but about parking spaces that are not privatized as sources of income but rather as spaces whose accessibility is limited to certain people and the space where one can display their social status. This study aims to explore: (1) Why is the practice of using public parking spaces at UNHAS only accessible to certain people according to the signs installed in the parking areas?; (2) What is the process of changing the meaning of public parking spaces into private parking spaces with a cultural approach. 


\section{Method}

The study was conducted at UNHAS Tamalanrea Campus KM 10, Makassar between 2016 and 2018. This location was chosen because it has several very large capacity parking areas.

The study uses the method of observing investigations, and a deep understanding of the phenomena of the activities subject in the UNHAS parking space area. Research location of UNHAS Tamalanrea Campus KM 10, Makassar. Research time between 2016-2018. Data was generated through in-depth interviews with a number of informants, and observation of field conditions. Collecting physical field data and interviewing informants was carried out simultaneously at the same time. Informants come from a variety of positions, consisting of structural offials, lecturers, staffs, students, and guests. See Table 1.

Table 1. Data of the Informants

\begin{tabular}{|c|c|c|}
\hline No. & Informant & Number \\
\hline 1. & Structural Official & 18 \\
\hline 2. & Lecturer & 29 \\
\hline 3. & Staff & 25 \\
\hline 4. & Student & 55 \\
\hline 5. & Guest & 23 \\
\hline Tota & Number & 140 \\
\hline
\end{tabular}

The collected field facts were mapped to obtain patterns. The patterns are then processed using domain and taxonomic analysis. Domain analysis to get a cultural symbolic concept from the activity actors in the UNHAS parking space. The taxonomic analysis was carried out to explore the main domains that form the research problem, how is the symbolic culture practiced in accessing UNHAS parking spaces.

The people who were interviewed knew my presence and position as a lecturer and as a researcher at UNHAS. Recognizing that the data collected through this in-depth interview poses a risk to informants, ethically their names are withheld or camouflaged.

\section{Result and discussion}

\section{Zoning}

The UNHAS Tamalanrea campus is located in Jalan Perintis Kemerdekaan Street KM 10 towards East of Makassar City. The approximately 220 ha campus is the currently main campus and the second campus among three campuses owned by UNHAS. The first campus is located in Baraya Makassar. The third campus is located on Jalan Poros Malino, Gowa Regency. In 1980s, the campus was designed by architect consultant OD205 from the Netherlands. 
The campus has two main entrances called Pintu Satu and Pintu Dua. In addition to the two main entrances, the campus has another entrance known as Pintu Nol. The entrance to Pintu Satu is flanked by two artificial lakes. On the right and left side of Pintu Satu Street, the supporting activity zone becomes a place of interaction between campus residents and outside campus. Here placed religious facilities and sports. At the entrance of Pintu Dua is the Wahidin Sudiro Husodo Regional Hospital and the UNHAS Teaching Hospital.

The campus is designed based on a holistic paradigm that sees UNHAS as a unitary entity (Martosenjoyo et al., 2020:231-232). The data collected from field observations indicate that the main zoning designated for academic activities is located in the middle of the campus, surrounded by a ring road. Outside of the academic zoning to the right of the Southeast are residential facilities such as student dormitories and rental apartments (RUSUNAWA). To the left of the West are enclosure experimental gardens and animal husbandry (Google, 2020). See Figure 1.

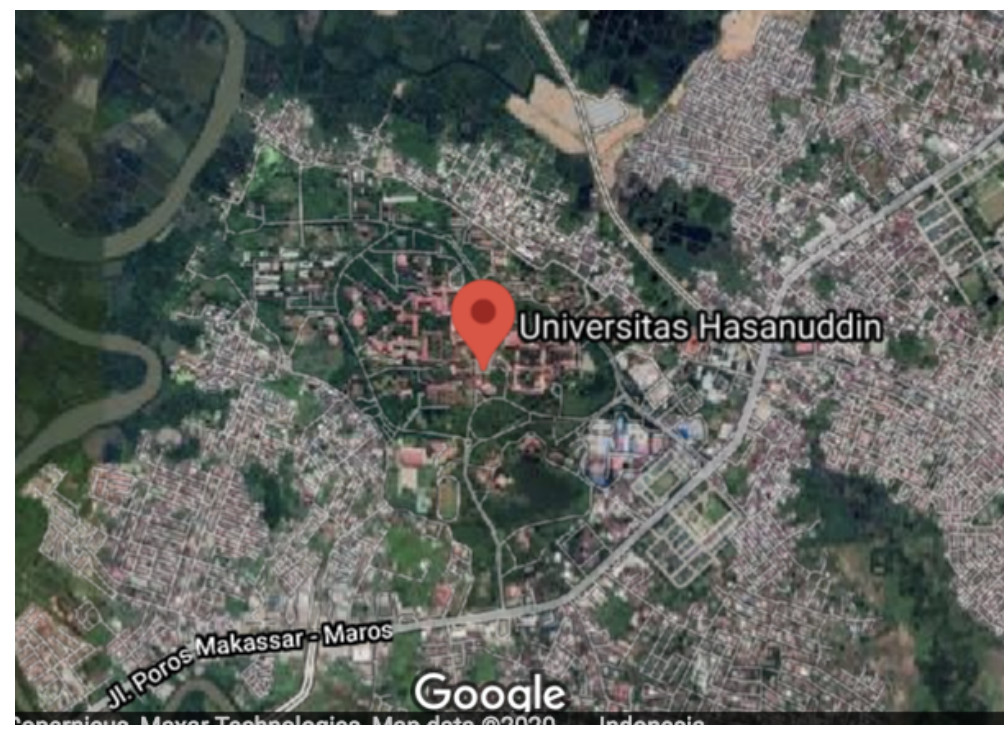

Figure 1. UNHAS Tamalanrea Campus (Google, 2020)

All facilities that support academic activities are located outside the academic zone, assuming that all facilities are owned by UNHAS that can be used by all UNHAS people in accordance with their respective rights and authorities. Likewise the use of parking spaces which can be accessed by everyone who are on the UNHAS Tamalanrea Campus. Parking facilities as supporting facilities are placed in the form of parking buildings or parking parks provided to support activities in the main building (Direktorat Jenderal Perhubungan Darat, 1996:2). At UNHAS, a parking lot merges with a very lush educational forest. Thus, parked vehicles are always protected from the sun.

When the campus is planned, parking spaces for four (or more) wheeled vehicles are not available within the academic zone except for service vehicle interests such as those in the library building, cages and experimental gardens, and canteen logistics. Within 
the academic zone are only available roofed bicycles and motorcycles with a relatively far distance from the office building or lecture hall. Thus, the sound of vehicles is not heard in these buildings. Parking zones of four or more wheeled vehicles as known as available cars spreadily park along the campus ring road in the form of parking bags shaded by lush trees. The parking zone outside this ring road has an area that is clearly separated from the activity center around it.

In its development, parking spaces for cars were originally and located only outside the ring road before began to be designed to enter into centers of activity, including academic zoning. Parking spaces are designed to unite or are attached to the existing building. The parking area for bicycles and motorcycles are not functioning because due to its location are far from the SATPAM 1 post, making it prone to criminal acts because it is difficult to monitor by the supervision system. Bicycle and motorcycle parking then follows the car park created which integrates with the building for easy monitoring.

There are three reasons why parking zones has no longer follow the initial concept of this campus development. First, the existence of work unit autonomy which made the holistic concept of UNHAS abandoned. UNHAS has no longer seen as a unitary entity, but rather as a combination of work units. For this reason, work units are allowed to be creative according to their respective interests. Second, the autonomy of the work unit does not require close coordination with the rector. Work units simply report what they do based on their work units' Annual Work Plans and Budgets. Coordination is only on managing the budget and not on physical activity. Third, architects who design parking spaces only make designs according to the wishes of the work unit.

There is no obligation to follow the existing campus master plan. Therefore, no master plan orientation was found. Each architect can be creative according to the direction of the work unit and their respective architect's insights. Several informants who were assigned to the UNHAS Equipment Section stated that they only received the planning drawing from the work units and did not have the authority to evaluate them because the evaluation was carried out by the auction committee. Architects who have been appointed directly only communicate with the unit leader without involving the Equipment Section except for administrative matters.

\section{Accessibility}

Campus parking spaces that are pulled in are attached to the buildings of this work unit into a closed zone marked by the presence of a three-to-four diameter iron pipe bar painted in black, called portal. This portal crosses the width of the driveway, blocking vehicles from entering the parking space. At one end of the beam is given a concrete pendulum which functions as a ballast, and the other end is given a plastic rope. If the plastic rope is loosened by the guardian, the concrete pendulum will drop

\footnotetext{
1 SATPAM stands for satuan pengamanan (security unit).
} 
towards the ground. Horizontal iron pipe bars will move in the vertical direction. The driveway then opens and the vehicle can pass into the parking space.

The officer who opens and closes the entrance to the parking space works from 08:00 to 16:00. The iron bar is horizontal if the work unit no longer has activities. Vehicle owners who are still on campus after hours will move their vehicles to a parking area that is considered safe, for example to parking spaces close to the SATPAM area (Identitas, 2019; Bone, 2020; Syukur, 2017).

A SATPAM informant stated that the vehicle owners do not feel their vehicle are safe because the parking areas are no longer guarded and the iron bars are in a vertical position. The iron bar is left in a vertical position so that the vehicle can go in and out without being treated by an open guard whose working hours have ended. When the iron bar position is vertical, the parking area is assumed to be in the state of low security system, and it is very common to hear the lost of a sufficient number of motorcycle.

To enter the parking space, officers will see who is driving the vehicle. If the rider is known as a member of the work unit, the officer will open the bar. If not known, the officer will ask the driver's interest to enter the parking space. For work units with limited parking space, officers will refuse to open the door if the driver of the vehicle is a student. Exceptions are given for Master and Doctoral students, or if the student has a close relationship with or is well known by the officer. When the parking area is full, drivers will park their vehicles along the shoulder of the road around the building to their destination.

In some work units with relatively large parking facilities, visible signages in the form of writing on the kansteen. It is a wall $10 \mathrm{~cm}$ high which form a border between the parking space floor and the land outside it. The writing is the vehicle numbers owned by the work unit officials such as DD XXX or DD YYY. Therefore, the space may not be used by others than those whose vehicle plate number matches with the existing markings.

In 2012 in the courtyard of the rectorate building, a sign appeared in the form of a 40c $\mathrm{m}$ circular iron plate, painted in a blue iron pole standing in front of the building. The blue circle bearing the letter $\mathrm{P}$ is equipped with the names of positions such as Rektor, Wakil Rektor I (WR I), Wakil Rektor II (WR II), Wakil Rektor III (WR III), and Wakil Rektor IV (WR IV). These signs indicate that only the vehicle of the Rector and Vice Rector can be parked in this area (see Figure 2). The staff of the household unit who made the signs stated that the high officials of the rectorate wanted that when they left the Rectorate building, they could immediately find their respective car.

In 2017, a footpath with a surface of $10 \mathrm{~cm}$ above the yard was built in this area. The placement of this path makes the parking area very narrow and impedes circulation paths in and out of the vehicle. The signs were then moved to a wider area around the baruga's main entrance to the Rectorate Building. 


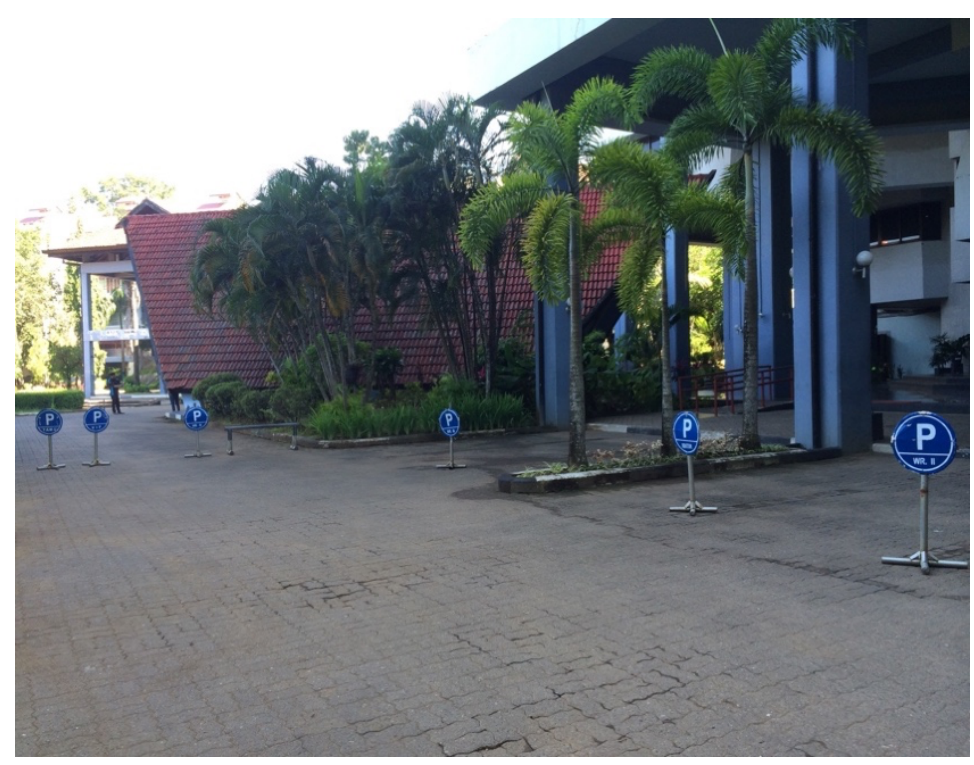

Figure 2. Private parking signages in Rectorate Building (Source: Triyatni)

In the parking area across the street from the location of the Rectorate Building, rectangular shaped metal plates bearing the names of various positions in the rectorate are standing. This signages are placed in the first row of parking spaces close to the Rectorate Building. When the parking space area is very congested, despite the fact that the vehicle according to the position is absent, the space is left empty (see Figure 3).

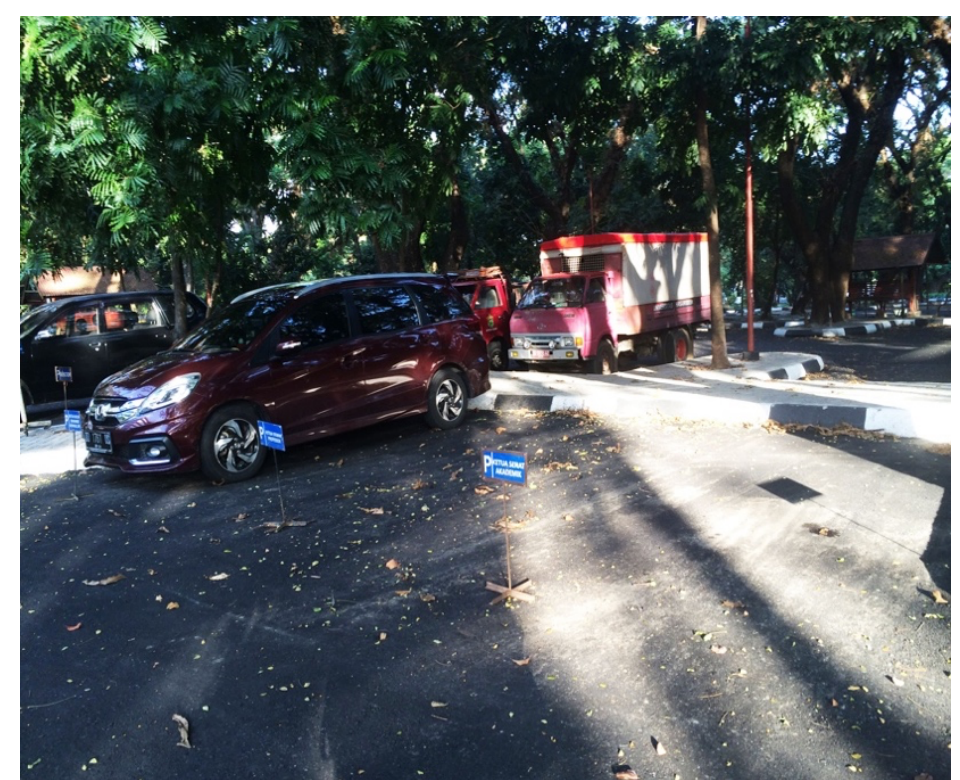

Figure 3. The parking area is empty with the signages written with the name of the position. (Source: Triyatni)

Signages in parking space are symbol systems that provide directions, identification warnings, and information to parking facility users and are a way of communicating with users, those who have never been to the place before (Smith, 2002:333). Symbols guide users to do or not do something. Not all signages in the parking space are 
obeyed by users. For example, many visible locations marked with prohibited parking sign still filled with vehicles.

Several incidents show users who find it difficult to find a parking space decide to park their vehicle in a prohibited area. The security guard did not appear to have the courage to reprimand. They expressed concern about preventing if the person being reprimanded was someone important. At UNHAS, it was not uncommon for a low status person to reprimand those with high status.

But for marked parking areas, users cannot use it, because the signs in pairs are located right in front of the vehicle parking area. When the vehicle owner enters the parking space, SATPAM will lift the sign and put it back when the vehicle is parked. This shows that the marking is obeyed when it is attached with certain number of vehicle, indicating that the vehicle belongs someone with certain position, and therefore parking in this area is not allowed for others.

Public space is a social space formed through interaction and social communication based on plurality. Plurality is a condition or prerequisite for human action because we are all the same (Arendt, 1958; Langgut-Terre, 2011:6-7). These are called events and events "public" when they are open to everyone (Habermas, 1991:2). Therefore, to create a public space, four conditions are needed, namely: (1) the status of the person is not questioned; (2) the material discussed is something that has not been questioned before, both by the state and by the community; (3) Decisions made are based on rational discussion; and (4) The intended public is inclusive (not exclusive).

Paradigm concept of "public" is a cultural thought (Sennett, 2010; Geertz, 2013; Pachenkov \& Voronkova, 2013; Gofmann, 1971). The meaning of "public" as a space or realm, but also as a "place". What happened to the public space show that public space is a "meeting place" and not just that "people move through space" (Arendt, 1958; Habermas, 1991). Public space is as "a place where strangers meet" (Sennett, 2010).

The public space paradigm is based on the philosophy that the main quality of public places is anonymity. If the meeting places that are not public can only be accessed by people who know each other, the meaning of public space can be accessed by anyone who does not know each other. Interaction that occurs in public space is a meeting people who do not know each other- and not just a silent and stupid movement through the boundaries and boundaries of space (Sennett, 2010:261-272).

The events that occurred in the parking space of the Rectorate Building and work units at UNHAS indicate that public parking spaces have changed their functions to private parking spaces because they are no longer open and can only be accessed by people who are known or known identity. The absence of anonymity of users of these parking spaces. The iron bar and other symbolic signs placed in the parking area signaling the exclusiveness of the space. There is no longer the anonymity in parking spaces that characterizes publicity. When anonymity is lost, the characteristics of the public space disappear. 


\section{Etalage}

While visiting one of the faculties, I met a leader of financial management who made a parking policy. Across the street in front of the faculty lies a public parking space that can hold dozens of four-wheeled and two-wheeled vehicles. Ms. Astuti, a finance officer I met expressed reluctance to use the parking space and chose to build a new parking space facility in the location of a protective plant area in the yard of the Dean Building.

The reason is that parking spaces are used for everyone and not for those associated with the faculty only. She divided the parking area between four-wheeled vehicles with and two wheels. Parking for cars is placed directly in the opposite the wall where the main entrance of the dean building is located. Motorcycle vehicle is placed in the farthest area from the entrance of the dean. This is because she want people know that faculty members are those who used private cars to the campus and not motorcycles which is associated with economically weak users.

The etalage also called storefront or show window is a term for cabinets, boxes, or glass shelves that are used to display a variety of valuables. The etalage position is directly located across the street (Wikipedia, 2020; The Free Dictionary, 2020). The storefront emerged as the first point of contact between buyers and traders. The buyer sees the goods offered and the traders tries to get the goods offered by the buyer.

In the display case the best items in the shop are displayed with the aim of grabbing the attention of buyers who are passing in front of the store, so that they are lured in and want to buy the items. Everything that customers see and experience in front of the storefront is linked together and shapes their overall perception of a store. The etalage is a key player in communication between buyers and sellers (Green, 2011:4; Khalili, 2017:13).

The study indicates that when a driver enters the UNHAS parking space, he will walk along the hallways of the parking lot while observing the empty parking area. Generally, drivers look for the closest space to the building's destination. During the busy working hours (between 10:00 AM to 14:00 PM), it is very difficult to get the nearest parking area to the work unit. In the parking space across the road from the Rectorate Building, drivers sometimes get a third-line parking area which is the last line of parking space or to park their vehicles outside the parking area along the shoulder of the road.

When users walk from the parking area of their vehicles to the Rectorate Building, they glance at the parking area marked with the names of positions in that building. Some of them took the time to have a dialogue with SATPAM, which is usually around the parking spaces. They asked about matters related to the position written on the signage. Users usually stop for a moment when pass through the parking area looking at the row of expensive luxury cars, the new product while showing a face of admiration. When meeting with other users, they dialogue about the characteristics and specifications of the car and its price. Dialogue like this is common: 
User: This is a cool car. Who owns this car?

SATPAM: Prof. Badu.

User: Who is he?

SATPAM: The boss from finance unit.

User: Wouw, it is very high specs!

SATPAM: How much is it?

User: Very expensive.

Parking space in the yard of the Rectorate Building and in front of this building is a space to show off and to promote vehicle owners' social status. Parking space is like an etalage for vehicles belongs to high-ranking officials. Displaying social status is significantly important for the people in South Sulawesi, and more specifically for the Bugis-Makassar society. Before the 1980s, patronage relations between leaders and followers is indicated through their nobility (Pelras, 2006:382).

Likewise, what happened at UNHAS, the majority of UNHAS community are BugisMakassarese. After the 1980s, patronage relations expanded, which not only taking into account the ascribed status (i.e. puang), but also achieved status, including academic degrees. The sensation of nobility is especially felt when the subordinates served their high-ranking officials who had academic degrees, calling them by an aristocracy title, puang. They are served like a king. This can be seen from how they are treated, which may be varied from opening and closing car doors when they use official cars, lifting bags, providing food and drinks, to taking care of family affairs, including paying bills for electricity, telephone and others. Subordinates in the rectorate change their summons to their leaders from addressing them with their aristocratic title (puang) to academic title (i.e. professor).

After 2010, officials were generally lecturers of work units that were not yet popular for the elite UNHAS environment in the Rectorate Building. These officials have doctorates and/or professors. At this time, those who are professors and/or have doctoral degrees are common among UNHAS lecturers. Consequently, the academic titles held by these officials are no longer exclusive to represent status symbols.

One of the administrative staff states that in general, they only know people who have often be seen in the Rectorate Building before they have high ranking position. But, those whose presence in the Rectorate Building is only after they have become high ranking officials are seen as new comers or even strangers. As a form of respect for them, the staff address them according their position, such as Bu Rektor, Pak WR, Pak Sekun, Pak Direktur, Pak or Bu Karo, Pak or Bu Kabag, Pak or Bu Kasubag, etc. ${ }^{2}$

\footnotetext{
2 Rektor. Rector.

Wakil Rektor. Vice Rector.

$\mathrm{Bu}$. Shortness of $\mathrm{Ibu}$. Ms.

Pak. Shortness of Bapak. Mr.

WR. Abbreviation of Wakil Rektor. Vice Rector.

Sekun. Abbreviation of Sekretaris Universitas. University Secretary.

Karo. Abbreviation of Kepala Biro. Head of Bureau.

Kabag. Abbreviation of Kepala Bagian. Head of Division.
} 
For UNHAS officials, having a special parking space is important, especially those who do not get official driver facilities. This is because, it is difficult to get a parking space near the building, as a result they have to walk long enough to get to the building. Some of them stated that they are not young anymore and so easily tire when they have to walk far distances.

In the past, the limited access of parking space was in fact happened in the late 2000s. Marked parking spaces are mostly given to education staff, such as Kepala Biro, Kepala Bagian, Kepala Sub-Bagian. This is because there were only five high ranking officials, namely: a rector and four vice rectors, the parking space was dominated by administrative staff. Accordingly, strong criticism from some lecturers who are in the level of doctors as well as professors from work units significantly emerged because they considered that their social status is inferior to administrative staff. As a result, the policy regarding private parking was abolished, except for high-ranking officials.

\section{Conclusion}

The study indicates that parking spaces are not just a place to park vehicles that are not being driven. UNHAS parking space is clearly seen that the function as a public space that can be freely accessed turning to be a private space.

This was due to planning that changed from a holistic concept to one based on autonomy. The concept of zoning planning for parking bags which was initially managed by the university (rectorate) has changed to be managed by work units. As a result, public parking facilities that were initially accessible to all users on campus have become accessible only to users who have a relationship with their respective work units.

The parking zoning change that was originally located outside the ring road has changed to be closer to the work units. Asset management based on work units makes a strategic parking area an opportunity to show off the social status of high-ranking work units. These strategic areas become a storefront to promote who are the important people in these work units. Those who are just ordinary users have no right to use it. Public parking spaces are privatized for the benefit of those associated with the management system into private parking spaces.

These findings demonstrate that the public paradigm promoted by Arendt and Habermas is not yet universal. Public space which becomes private space has marginalized others who do not have high social status or do not have certain social status and/or position. In other words, they lost their right to the public space because of the privatized public space.

The limited number of built environment facilities must be accessible to all without a difference in status. If facilities that are supposed to be public for reasons of cultural subjectivity changes to become private, then the opportunity for spaces where people

Kasubag. Abbreviation of Kepala Sub-Bagian. Head of Sub-Division. 
who don't know each other meet will disappear. Improving the quality of insights about the importance of equal public rights to accessibility must always be a serious concern. In addition, public space must still have a social function and must not be changed into a private space for subjective reasons.

\section{Acknowledgments}

My respect goes to all participants and editors who have done well until this article can be published.

\section{Conflicts of interest}

Author declares no conflict of interest.

\section{References}

Arendt, H. (1958). The Human Condition. Chicago: The University of Chicago.

Ashton, P.; Doussard, M.; and Weber, R. (2012). "The Financial Engineering of Infrastructure Privatization What Are Public Assets Worth to Private Investors?", Journal of the American Planning Association, 78 (3): 300-312.

Auchincloss, A. H.; Weinberger, R.; Aytur, S., Namba, A.; and Ricchezza, A. (2015). "Public Parking Fees and Fines: A Survey of U.S. Cities", Public Works Management E Policy, 20 (1): 49-59.

Bone, M. N. (2020, April 3). Sering Beraksi di Kampus Unhas Makassar, Maling Spesialis Cungkil Jok Motor Digerebek Polisi, Retrieved Juli 2, 2020, from iNewsSulsel.id: https://sulsel.inews.id/berita/sering-beraksi-di-kampus-unhas-makassarmaling-spesialis-cungkil-jok-motor-digerebek-polisi, accessed July2, 2020.

Direktorat Jenderal Perhubungan Darat. (1996). Keputusan Direktur Jenderal Perhubungan Darat Nomor : 272/Hk.105/Drjd/96 Tentang Pedoman Teknis Penyelengaraan Fasilitas Parkir. Jakarta: Direktorat Jenderal Perhubungan Darat. . Jakarta: Direktorat Jenderal Perhubungan Darat.

Geertz, C. (2013). "Religion as a Cultural System", in M. Banton (ed.), Anthropological Approaches to the Study of Religion. London: Routledge, pp. 1-46.

Gofmann, E. (1971). Relation in Public. New York: Basic Books, Inc. Publisher.

Google. (2020). Google Map, https://www.google.co.id/maps/place/Universitas+Hasanuddin/@5.1376382,119.4867903,389m/data=!3m1!1e3!4m5!3m4!1s0x2dbefd98efd2e6b3:0x 84d7ba8216749060!8m2!3d-5.1324075!4d119.4883782?hl=en, accessed on June 14, 2020.

Green, W. R. (2011). The Retail Store - Design and Construction (2nd edition). San Jose: iUniverse.com, Inc.

Habermas, J. (1991). The Structural Transformation of The Public Space, An Inquiry into A Category Of Bourgeois Society. Cambridge: MIT Press.

Identitas. (2019). Satpam Unhas Bekuk Dua Pelaku Pencuri Motor. https://identitasunhas.com/satpam-unhas-bekuk-dua-pelaku-pencuri-motor/, accessed on July 2, 2020

Khalili, A. M. (2017). “Creativity in Store Design - A Study on the Influential Role of Store Design and Storefront Design in a Relationship with Urban Perception to Present a Brand", Architecture Research, 7 (3):92-17.

Koops, B. J., and Galič, M. (2017). "Conceptualising Space and Place: Lessons from Geography for the Debate on Privacy in Public", in Timan, T; Newell, C. C.; and 
Koops, B. J. (eds.), Privacy in Public Space: Conceptual and Regulatory Challenges. Cheltenham: Edward Elgar Publishing, pp. 19-46.

Langgut-Terre, E. (2011). Manusia Politis Menurut Hannah Arendt - Pertautan antara Tindakan dan Ruang Publik, Kebebasan dan Pluralitas, dan Upaya Memanusiakan Kekuasaan. Jakarta: Komunitas Salihara.

Martosenjoyo, T.; Naping, H.; Rahim, M. R.; and Lampe, M. (2020). "Public Toilets, Stink, and Power", The Asia Pacific Journal of Anthropology, 21(3): 229-247.

Nasution, A. D., \& Zahrah, W. (2012). Public Open Space Privatization and Quality of Life, Case Study Merdeka Square Medan. In M. Y. Abbas, M. Y.; Bajunid, A. F.; and Azhari, N. F. (eds.), ASEAN Conference on Environment-Behaviour Studies, The Other Space: Policy, Culture and Human Behaviour. 36, pp. 466-475. Amsterdam: Elsevier, pp. 466-475.

Neal, Z. P. (2010). "Locating Public Space", in A. M. Orum, A. M. and Z. P. Neal, Z. P. (eds), Common Ground? Readings and Reflections on Public Space. New York: Routledge: Taylor and Francis, pp. 1-12.

Pachenkov, O., \& Voronkova, L. L. (2013). “Urban Public Space In The Context of Mobility and Aestheticization: Setting The Problem Institute for European Ethnology", in Pachenkov, O. (ed.), Workshop Introductory Speech: Urban Public Space In The Context Of Mobility And Aestheticization: Facing Contemporary Challenges, Frankfurt: Peter Lang GmbH, pp. 13-30.

Pelras, C. (2006). Manusia Bugis. Jakarta: Nalar, Forum Jakarta-Paris.

Sennett, R. (2010). "The Public Realm", in Bridge, G. and Watson, S. (eds.), The Blackwell City Reader. (pp. 261-272). London: Blackwell Publishers, pp. 261-272.

Smith, M. S. (2002). "Signage", in Chrest, A. P.; Smith, M. S. Buyan, A.; Monahan, D. R.; and Iqbal, M. (eds.), Parking Structure - Planning, Desgn, Construction, Maintenance, Repair. Boston: Kluwer Academic Punlishers, pp. 333-398.

Syukur. (2017). Dua Pencuri Motor di Unhas Tertangkap Basah, http://news.rakyatku.com/read/52271/2017/06/10/dua-pencuri-motor-diunhas-tertangkap-basah, accessed on July 2, 2020.

The Free Dictionary. (2020). Storefront, https:// www.thefreedictionary.com/storefront, accessed on July 6, 2020.

Tilley, C. (1994). A Phenomenology of Landscape Places, Paths and Monuments. Oxford, Providence: Berg.

United Nations Educational, Scientific and Cultural Organization. (2017). Inclusion Through Access to Public Space Definition, http://www.unesco.org/new/en/social-and-human-sciences/themes/urbandevelopment/migrants-inclusion-in-cities/good-practices/inclusion-throughaccess-to-public-space/, accessed on July 11, 2020.

Wikipedia. (2020). Etalase, https://id.wikipedia.org/wiki/Etalase, accessed on June 20, 2020. 